\author{
Alexandra Krivosikova, \\ Slovak University of Agriculture in Nitra, Slovakia \\ Jana Rybanska, \\ Ph.D., Slovak University of Agriculture in Nitra, Slovakia \\ Ludmila Nagyova, \\ Ph.D., Slovak University of Agriculture in Nitra, Slovakia \\ Andrej Geci, \\ Slovak University of Agriculture in Nitra, Slovakia
}

\title{
CONSUMER BEHAVIOUR OF SENIORS ON THE COW'S MILK MARKET IN SLOVAKIA: SILVER PERSUADING TECHNIQUES
}

\begin{abstract}
Seniors are usually perceived as an unattractive segment, mostly due to their limited spending power. In Slovakia, the number of seniors has continuously been increasing. The population has been growing older. In Europe, more than a quarter of the population is expected to be aged 65 years or older by 2050. That is the main reason why we have to understand the consumer behaviour and decision-making processes of senior consumers. The presented paper deals with the consumer behaviour of seniors on the Slovak market of cow's milk since it is the most commonly consumed type of milk in Slovakia. Opinions of nutrition specialists differ on whether it is beneficial or not for humans to consume milk. However, in general, milk is considered to be an essential component of the diet not only for children but also for adults and especially for seniors because of its high nutrition value. Milk and dairy products should be a daily part of the seniors' diet. Since older people no longer have the necessary enzyme (lactase) to break down milk sugar (lactose), it is recommended to consume milk products that no longer contain milk sugar, but that lactic acid is produced by fermentation. Sour milk products such as curd, yoghurt or kefir have a beneficial effect on stomach, intestines and also the immune system. Long-term insufficiency of calcium intake causes osteoporosis - a disease that manifests itself in bone loss and structural disorders. It leads to increased fracturing of the bones and thus an increased risk of health complications resulting from there. This study explores senior consumers' preferences for milk and their decision-making strategies on the market of cow's milk. The study is oriented primarily on visual cues catching the attention of consumers. Anonymous survey was conducted on a sample of 470 senior respondents (210 males and 260 females) aged $61-84$. Using selected psychological tools and a short questionnaire it was found out that Slovak seniors prefer traditional motives and bright colours on the milk packaging, they highly prioritise price over quality of milk products and in comparison with young adults, they are loyal to chosen products or brands. Seniors who score higher on the scale of neuroticism personality trait state that the packaging of milk products is significant for their decisions. Seniors with higher emotional stability tend to experiment more on the market of milk.
\end{abstract}

Keywords: cow's milk, seniors, consumer behaviour, packaging, persuading techniques.

Introduction. Nutrition is the primary environmental factor, directly under human control, that interacts with genetic predisposition and influences human health (Barrea et al., 2017). Animal source foods are essential for people as they provide essential micro and macronutrients for human development and functioning (lannotti et al., 2017). Milk has been an essential food for humans since the domestication of dairy animals. It is a common component of the animal-derived food products that comprise many diets (Attaie, 2015).

Literature Review. Dairy products are part of the nutritional recommendations in many countries worldwide, stimulating the regular consumption of these products by several groups of consumers, including children and older people (Rozenberg et al., 2016; Lamanche et al., 2016) because milk is considered to be very complex and balanced food (Bartosovicova, 2011). Moreover, it contributes a significant proportion of daily requirements of protein and calcium at a population level (Huth, 2013). When fortified, milk also contributes to vitamin $\mathrm{D}$, which is with previously discussed substances, an essential nutrient for bone health

Cite as: Krivosikova, A., Rybanska, J., Nagova, L., \& Geci, A. (2020). Consumer Behaviour of Seniors on the Cow's Milk Market in Slovakia: Silver Persuading Techniques. Marketing and Management of Innovations, 1, 200-207. http://doi.org/10.21272/mmi.2020.1-16 

Silver Persuading Techniques

(Dawson-Hughes et al., 2010). Milk consumption also contributes to dietary intake of magnesium, potassium, phosphorus, vitamin B12, riboflavin and vitamin A (Lamarche et al., 2016).

Consumption of milk in Slovakia has a long tradition, and the industrial processing of milk has more than a century history. However, in the 21st century, the trend of consumption of drinking milk has a downward trend, excluding consumption of cheese, cottage cheese, sour milk products and butter (Kubicova, Kadekova, Dobak, 2014). Only a quarter of older people consume the recommended daily amount of dairy products (Belardi, 2015), although, they should eat at least one dairy product (yoghurt, sour milk, curd, low-fat cheese) every day, which is alarming. According to the latest findings, because of that, older people do not get the correct amount of calcium and protein (Hudecova, 2018).

Given the changing consumption patterns on milk market, it is increasingly essential for those in the dairy supply chain to understand consumer preferences in order to meet their rapidly evolving demands (The Dairy Alliance, 2019). The current situation on the market has put a consumer into the position of major decisive and leading element of a market (Kurajdova, Taborecka-Petrovicova, 2015). Unfortunately, seniors have been usually viewed as an unattractive market due to the perception that they had limited spending power. However, in the Slovak Republic, they are nowadays quite a significant segment, because in 2016 the share of the elderly (65 or over) among the total population was 14.4\% (in comparison in 1996 it was just 10.9\%) and this share is still growing, and it is expected to reach $25 \% 2050$. The purchase behaviour of older consumers differs somewhat from that of their younger counterparts. Many authors (Moschis, 2003; Pettigrew et al., 2005; Petterson, 2007) have specified such differences, which include: expecting personal attention and special services, considering shopping to be asocial event, perceiving brand and retailer reputation, more extended time in purchase decision-making, increased store loyalty, etc. Given the range of differences noted, retailers need to give them serious consideration and use them to differentiate their services to different consumer segments.

Methodology and research methods. Anonymous survey was conducted on a sample of 2104 respondents of different age groups, but in our study, we work with a sample of 470 senior respondents (210 males and 260 females) aged 61 - 84. The Chi-Square Test for Goodness of Fit was used to test whether this sample is representative:

$\mathrm{H}_{0}$ : a sample is a representative.

$\mathrm{H}_{1}$ : a sample is not representative

Critical value $(3,84)$ had a higher value than test characteristics $(0,99)$. Hence the null hypothesis was accepted, and within $95 \%$ probability, this sample reflects the real gender distribution in Slovakia. All respondents have completed at least secondary education, and they live in Slovakia (Figure 1).

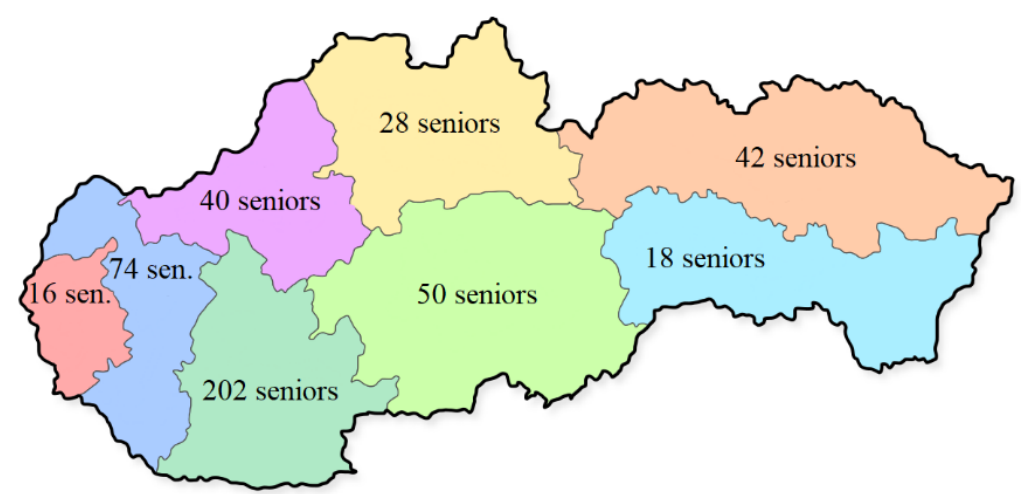

Figure 1. Settlement of respondents according to Slovak districts

Source: developed by the authors. 
A. Krivosikova, J. Rybanska, L. Nagova, A. Geci. Consumer Behaviour of Seniors on the Cow's Milk Market in Slovakia: Silver Persuading Techniques

Three hundred ten respondents live in rural areas near bigger towns and cities; 160 respondents live directly in towns and cities. All respondents are retired, but 88 respondents work alongside retirement. Information about respondents' income is stated in Table 1.

Table 1. Respondents according to their income

\begin{tabular}{|c|c|c|c|c|c|}
\hline & \multicolumn{3}{|c|}{ Monthly income (gross) } & \multirow{2}{*}{ Total } \\
\hline & & less than $480 €$ & $480-1000 €$ & more than $1000 €$ & \\
\hline \multirow{2}{*}{ Gender } & Male & 114 & 82 & 14 & 210 \\
\hline & Female & 198 & 54 & 8 & 260 \\
\hline \multicolumn{2}{|c|}{ Total } & 312 & 136 & 22 & 470 \\
\hline
\end{tabular}

Source: developed by the authors.

A questionnaire was constructed to achieve the research objectives. A questionnaire consists of several parts and takes into consideration possible physical, functional and sensory limitations of senior respondents. The first part represents the short personality inventory based on the Big Five Model (NEO FFI). Four personality traits were investigated - neuroticism $(N)$, extroversion $(E)$, openness to experience $(O)$ and conscientiousness $(\mathrm{C})$. The traits that constitute the five-factor model are extraversion, neuroticism, openness to experience, agreeableness, and conscientiousness. Extraversion sometimes referred to as surgency, is indicated by assertive, energetic, and gregarious behaviours. Neuroticism is substantially equivalent to emotional instability and can be seen in irritable and moody behaviours. Openness to experience sometimes referred to as intellect, indicates an individual's inquisitiveness, thoughtfulness, and propensity for intellectually challenging tasks. Agreeableness is indicated in empathic, sympathetic, and kind behaviours. Finally, conscientiousness refers to an individual's sense of responsibility and duty as well as foresight (Grice, 2019). The second part of the questionnaire represents a basic association experiment. Respondents were asked to write down words that occurred to them when they hear/see a word «milk» and words that occurred to them when they hear/see a word «packaging of milk». The third part consists of several statements connected to the consumption of milk and buying behaviour on the market of milk. Respondents were asked to express if they agree or disagree with mentioned statements on the 5-degree Likert-type scale. Last part of the questionnaire gathers demographic information about respondents.

Data was collected personally with the help of trained professional (psychologist) and via an online form with a detailed description. The dependences between psychological characteristics of respondents and their preferences were investigated by suitable statistical methods (Kruskal-Wallis one-way analysis of variance, ordinal logistic regression analysis and correlation analysis). We will determine the probability level - alpha $(a=0.05)$, which will be compared to the significance level ( $p$-value). Based on alpha $(a)$, we can evaluate the dependence with the $p$-value comparison. If the $p$-value is lower than alpha $(a)$, we will refuse $\mathrm{H}_{0}$. If the $\mathrm{p}$-value is higher than alpha (a), we will not refuse $\mathrm{H}_{0}$.

Results. Based on the short personality inventory, it was found out that $43 \%$ of respondents are not open to new experiences; they are rather conservative. $57 \%$ of respondents achieved high scores in openness to experience. $51.9 \%$ of respondents scored highly on the scale of neuroticism. Individuals who score high on neuroticism tend to be moodier and more often experience anxiety, sadness and similar negative feelings. A high incidence of higher neuroticism in the sample may be caused by deteriorating health state or social and environmental factors that are connected with higher age. Some research confirmed this assumption; for example, Barefoot et al. (2001), Lowe and Reynolds (2006), Chapman (2007). The team of Berafoot et al. (2001) argues that a higher assessment of depressive states was in women than in men. While women showed an increase in depressive symptoms from 50 to 60 years of age, men showed these symptoms from 50 to 80 years of age. The explanation is, therefore, evident, and the differences involved include changes in social roles and ageing. The second group of authors reaffirmed the results. Lowe and Reynolds (2006) 

Silver Persuading Techniques

examined two samples of respondents in their research. The first sample was 226 adult respondents, aged 60 and over. The second sample was 863 elderly responders at the same age. In both cases, time stability and construct validity were examined through which were confirmed various aspects of anxiety. In his survey, Chapman (2007) explored not only young adults but also middle-aged respondents and was finding out whether the critical responses were sufficient covariance among the selected items. In this survey, respondents also confirmed a higher value of neuroticism caused not only by social but also environmental factors.

$68.5 \%$ of respondents claim that they are conscientious, and almost $46 \%$ of respondents are introverted. Representation of extroversion in the sample corresponds with the anticipated representation of this characteristic in the worldwide population. Researchers state that there are $50-75 \%$ of extroverts in the worldwide population, but all sources are inconclusive. No research would prove the exact worldwide distribution of extroversion. Only 378 of 470 respondents $(80.4 \%$ ) in the sample consume cow's milk (Figure 2). Respondents who do not consume cow's milk suffer from different health problems (allergy, intolerance, other health issues) or they do not like the taste of milk. Respondents who do not consume cow's milk completed the adjusted association experiment but were excluded from further research.

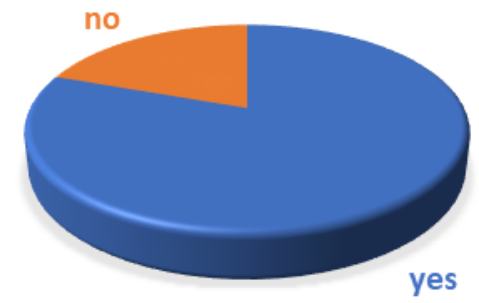

Figure 2. Consumption of cow's milk by Slovak seniors

Source: developed by the authors.

The association experiment has shown the leading associations that consumers have with milk and milk packaging. The results are stated in Table 2.

Table 2. Associations that senior consumers have with «milk» and «milk packaging.»

\begin{tabular}{|c|c|c|}
\hline & Association with milk & Association with milk packaging \\
\hline $\begin{array}{c}\text { Answers of } \\
\text { seniors }\end{array}$ & $\begin{array}{c}\text { cow, white colour, health, cheese, childhood, } \\
\text { semolina pudding, a specific brand of milk products }\end{array}$ & $\begin{array}{c}\text { use-by date, cows, white colour, blue colour, } \\
\text { nature, grass, a glass of milk, cardboard box, } \\
\text { traditional motives }\end{array}$ \\
\hline
\end{tabular}

Source: developed by the authors.

The leading associations of Slovak senior consumers represent logical associations of the product's environment and qualities (cow, white colour, health) and presumable childhood memories. Childhood memories have proven to be an essential choice factor in the survey from Carvalho et al. (2016). This author mentions childhood memories as a significant factor in human impact. The results also suggested a significant influence of parental behaviour on respondents in adult age. Senior consumers also associate milk with specific brands that sell cow's milk on the Slovak market. It is the main reason that associations of consumers in the sample for «milk packaging» are probably biased by already existing packaging. The similar association experiment was conducted among young adults (Millennials) aged 25-42 from Nitra region (Rybanska et al., 2019) whereas the team of authors claims that the word «milk» is the first thing that comes to mind when 
A. Krivosikova, J. Rybanska, L. Nagova, A. Geci. Consumer Behaviour of Seniors on the Cow's Milk Market in Slovakia: Silver Persuading Techniques

speaking about the package. Not just the material itself in which the milk is sold, but also the graphic (colour) of the packaging. The results (for comparing) are stated in Table 3.

Table 3. Associations that young adult consumers have with «milk» and «milk packaging»

\begin{tabular}{|c|c|c|}
\hline $\begin{array}{c}\text { Answer of } \\
\text { Millennials }\end{array}$ & $\begin{array}{c}\text { Association with milk } \\
\text { lactose, chocolate, bones, breakfast }\end{array}$ & Association with milk packaging \\
\hline
\end{tabular}

Source: developed by the authors.

It assumes that associations of seniors and Millennials are quite similar. Older adults seem to be more pragmatic; they associate the packaging of milk with typical packaging features and qualities (use-by date, cardboard box, traditions). Further research has shown that Slovak seniors prefer traditional motives and bright colours on the milk packaging. The importance of packaging in a selected group of the population was also investigated in the survey Ares et al. (2010). The team of authors concluded that the package (with the presence of the image) was the variable with the highest relative importance. The importance of this variable was high, suggesting that the package plays an essential role in the perception and purchase of food by consumers. Kruskal-Wallis one-way analysis of variance has shown (Figure 3 ) that there is a significant difference in the subjective importance of milk price among respondents with different monthly income $(p=$ 0,001). The higher is the monthly income of respondents, the less important is the price of milk.

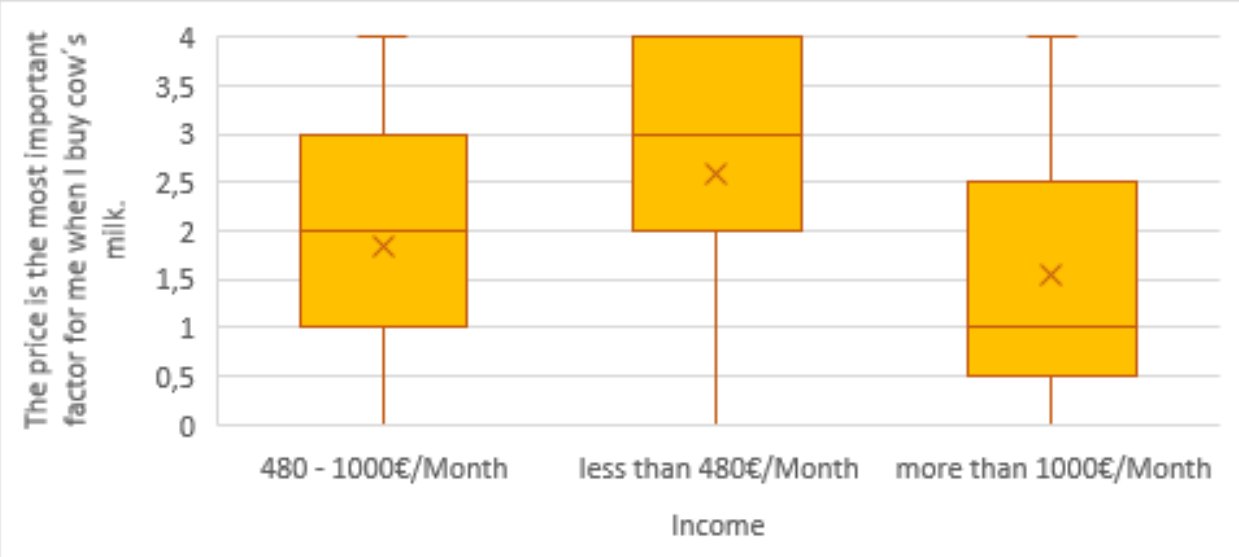

Figure 3. Different importance of milk price among Slovak seniors

Source: compiled by the authors.

The Slovak seniors have, in most cases, low income, so they highly prioritise price over quality of milk and milk products. Despite this result, almost $70 \%$ of respondents stated that they prioritise quality over the price. Further questioning has shown that in comparison with young adults, seniors tend to be more loyal to chosen products or brands. This result regarding the loyalty of seniors was also confirmed in the survey from Iver and Muncy (2005). The author points out that despite the perception of high parity among individual companies existing in the selected market, they can acquire and develop loyal customers. It proved no dependence between the income of respondents, and their tendency to buy milk based on packaging (Table 4) as the chi-square statistics is 5,237 , and the p-value is 0,732 , so the results were not significant at $5 \%$. The packaging of products is very often called a «silent seller», and consumers very often do not see its importance on the conscious level. The design of the package was also dealt with by Rundh (2009) and 
A. Krivosikova, J. Rybanska, L. Nagova, A. Geci. Consumer Behaviour of Seniors on the Cow's Milk Market in Slovakia: Silver Persuading Techniques

Suchanek and Kralova (2018), who demonstrates the impact of packaging on both external and internal consumer factors in his study. According to his results, a well-defined package can increase the customer's interest in the goods or promote the brand on the market.

Table 4. Importance of packaging by different income groups of seniors

\begin{tabular}{|c|c|c|c|c|}
\hline \multirow{2}{*}{$\begin{array}{c}\text { Importance of } \\
\text { packaging }\end{array}$} & \multicolumn{3}{|c|}{ Monthly income (gross) } & \multirow{2}{*}{ Total } \\
\cline { 2 - 4 } & less than $\mathbf{4 8 0} €$ & less than 480€ & less than 480€ & \\
\hline 0 & 68 & 30 & 6 & 104 \\
\hline 1 & 84 & 24 & 6 & 114 \\
\hline 2 & 76 & 30 & 8 & 114 \\
\hline 3 & 52 & 34 & 2 & 88 \\
\hline 4 & 32 & 18 & 0 & 50 \\
\hline Total & 68 & 30 & 6 & 470 \\
\hline
\end{tabular}

Source: developed by the authors.

That is why the dependence between the importance of packaging and individual personality traits were investigated. Based on ordinal logistic regression analysis, it was found out (Table 5) that neuroticism is a predictor of consumer behaviour when consumers buy milk based on its packaging.

Table 5. Results of ordinal logistic regression analysis

\begin{tabular}{|c|c|c|c|c|c|c|c|c|}
\hline \multicolumn{2}{|c|}{} & \multirow{2}{*}{ Estimate } & \multirow{2}{*}{ Std. Error } & \multirow{2}{*}{ Wald } & \multirow{2}{*}{ df } & \multirow{2}{*}{ Sig. } & \multicolumn{2}{|c|}{$95 \%$ Confidence Interval } \\
\cline { 8 - 10 } & & & & Lower Bound & Upper Bound \\
\hline \multirow{4}{*}{ Threshold } & {$[\mathrm{Q} 5=0]$} & $-0,476$ & 0,313 & 2,315 & 1 & 0,128 & $-1,089$ & 0,137 \\
\cline { 2 - 9 } & {$[\mathrm{Q} 5=1]$} & 0,582 & 0,307 & 3,598 & 1 & 0,058 & $-0,019$ & 1,184 \\
\cline { 2 - 9 } & {$[\mathrm{Q} 5=2]$} & 1,399 & 0,321 & 19,024 & 1 & 0,000 & 0,770 & 2,027 \\
\cline { 2 - 9 } & {$[\mathrm{Q} 5=3]$} & 3,056 & 0,379 & 65,156 & 1 & 0,000 & 2,314 & 3,797 \\
\hline Location & $\mathrm{N}$ & 0,045 & 0,011 & 17,252 & 1 & 0,000 & 0,024 & 0,066 \\
\hline
\end{tabular}

Source: developed by the authors.

Seniors who are less emotionally stable (score higher on the scale of neuroticism) state that the packaging of milk products is essential for their decisions. This fact has also been confirmed in research from Hills and Argyle (2001). The authors that were mentioned have conducted an empirical study that was measured by the Oxford Happiness Inventory $(\mathrm{OHI})$. They found out that the less emotional stability of the packages was more strongly associated with happiness than extraversion, and it represented more overall variability in multiple regression. Seniors with high emotional stability stated that the packaging was not so essential for them to more often. The similarity of the found result was also in the survey by Jang et al. (2005). In their study, the team of authors concluded that emotionally stable respondents did not attach importance to individual product packaging. The correlations among individual answers were found using the nonparametric correlation analysis. Respondents who consider milk to be a healthy beverage also state that the quality of milk is crucial for them (Spearman's rho $=0,244^{* *}$ ) and that they have a favourite brand of milk, which they buy the most often (Spearman's rho $=0,192^{* *}$ ).

Conclusions. The survey found that more than $80 \%$ of respondents consume cow's milk. The remaining percentage of asked people have different reasons why they do not consume this type of milk (health or personal reasons). Most respondents are controversial - they are not open to new opportunities and experiences. More than $51 \%$ of respondents have reached the range of neuroticism that causes moodiness and anxiety. The survey found out that older adults are more pragmatic, and they combine milk packaging with its typical packaging characteristics (e.g., sell-by-date). An important fact is that Slovak consumers prefer traditional motifs and transparent colours of milk packaging. Nearly $70 \%$ of seniors said they preferred quality 

Silver Persuading Techniques

over price. The importance of quality was confirmed by Valaskova, Kliestikova and Krizanova (2018), what may cause seniors to tend to be more loyal to selected products or brands. The survey confirmed that seniors are less emotionally stable, so the packaging of dairy products is essential in their decision making.

Based on the above mentioned, we can assume that the behaviour of the dairy market can affect the behaviour of manufacturers in this specific market. The way they perceive milk packaging can be influenced by the way consumers perceive milk. Also, packaging may affect their association with particular milk or other milk brands. Thus, we can say that milk packaging is essential for the perception of older adults and their subsequent behaviour in this market.

Author Contributions: conceptualisation, J. R. and A. K.; methodology, J. R.; validation, J. R., A. G. and A. K.; resources, A. K.; writing-original draft preparation, A. K.; writing-review and editing, A. K.; visualisation, L. N.; supervision, L. N.; project administration, L. N.; funding acquisition, L. N.

\section{References}

An Empirical Research. Journal of Competitiveness, 10(3), 149-163.

Ares, G., Besio, M., Gimenez, A. \& Deliza, R. (2010). Relationship between involvement and functional milk desserts intention to purchase. Influence on attitude towards packaging characteristics. Appetite. 55 (2), 298-304. [Google Scholar] [CrossRef]

Attaie, R., Bsharat, M., Mora-Gutierrez, A., \& Woldesenbet, S. (2015). Determination of withdrawal time for oxytetracycline in different types of goats for milk consumption. Journal of Dairy Science, 98 (7), 4370-4376. [Google Scholar] [CrossRef]

Barefoot, J. C., Mortensen, E. L., Helms, M. J., Avlund, K. \& Schroll, M. (2001). A longitudinal study of gender differences in depressive symptoms from age 50 to 80. Psychology and Aging, 16 (2), 342. [Google Scholar] [CrossRef]

Barrea,L., Di Somma, C., Macchia, P. E., Falco, A., Savanelli, M. C., Orio, F.,... \& Savastano, S. (2017). Influence of nutrition on somatotropic axis: Milk consumption in adult individuals with moderate-severe obesity. Clinical Nutrition, 36 (1), 293-301. [Google Scholar] [CrossRef]

Bartosovicova, M. (2011). Mliecne vyrobky. Preco su zdrave a niektore aj zdravsie? Retrieved from https://www.vedatechnika.sk/SK/VedaASpo locnost/NCPVaT/Stranky/Mliecne-vyrobky-Preco-su-zdrave-a-niektore-aidravsie.aspx Belardi, L. (2015). Study highlights low dairy intake among residents. Retrieved from https://www. australianageingagenda.com.au/2015/05/29/study-highlights-low-dairy-intake-among-residents/

Carvalho, C. B., da Motta, C., Pinto-Gouveia, J. \& Peixoto, E. (2016). Influence of family and childhood memories in the development and manifestation of paranoid ideation. Clinical psychology \& psychotherapy, 23 (5), 397-406. [Google Scholar] [CrossRef]

Chapman, B. P. (2007). Bandwidth and fidelity on the NEO-Five Factor Inventory: Replicability and Reliability of cluster subcomponents. Journal of Personality Assessment, 8822), 220-234. [Google Scholar] [CrossRef]

Dawson-Hughes, B., Mithal, A., Bonjour, J. P., Boonen, S., Burckhardt, P., Fuleihan, G. E., ... \& Yoshimura, N. (2010). IOF position statement: vitamin D recommendations for older adults. Osteoporosis International, 21 (7), 1151-1154. [Google Scholar] [CrossRef]

Grice, W. J. (2019). Five-factor model of personality. Encyclopaedia Britannica. Retrieved from https://www.britannica.com/science/five-factor-model-of-personality

Hills, P. \& Argyle, M. (2001). Emotional stability as a major dimension of happiness. Personality and individual differences, 31(8), 1357-1364. [Google Scholar] [CrossRef]

Hudecova, D. (2018). Strava seniorov ma svoje specifika. Retrieved from https://seniori.pravda.sk/poradna/clanok/469706-stravaseniorov-ma svoje-specifikal

Huth, P. J., Fulgoni, V. L., Keast, D. R., Park, K., \& Auestad, N. (2013). Major food sources of calories, added sugars, and saturated fat and their contribution to essential nutrient intakes in the US diet: data from the national health and nutrition examination survey (20032006). Nutrition journal, 121), 116. [Google Scholar] [CrossRef]

lannotti, L. L., Lutter, C. K., Stewart, C. P., Riofrio, C. A. G., Malo, C., Reinhart, G., ... \& Waters, W. F. (2017). Eggs in early complementary feeding and child growth: a randomised controlled trial. Pediatrics, 140 (1), e20163459. [Google Scholar] [CrossRef]

Iver, R. \& Muncy, J. A. (2005). The role of brand parity in developing loyal customers. Journal of Advertising Research, 45 (2), 222-

228. [Google Scholar] [CrossRef]

Jang, K. L., Dick, D. M., Wolf, H., Livesley, W. J. \& Paris, J. (2005). Psychosocial adversity and emotional instability: An application of gene-environment interaction models. European Journal of Personality: Published for the European Association of Personality Psychology. 19 (4), 359-372. [Google Scholar] [CrossRef]

Kubicova, L., Kadekova, Z., \& Dobak, D. (2014). Trends in consumption of milk and dairy products in Slovakia after EU accession. Polityki Europejskie, Finanse i Marketing, 12 (61), 90-97. [Google Scholar]

Kurajdova, K. \& Taborecka-Petrovicova, J. (2015). Literature review on factors influencing milk purchase behaviour. International Review of Management and Marketing, 5(1), 9-25. [Google Scholar] 
A. Krivosikova, J. Rybanska, L. Nagova, A. Geci. Consumer Behaviour of Seniors on the Cow's Milk Market in Slovakia: Silver Persuading Techniques

Lamarche, B., Givens, D. I., Soedamah-Muthu, S., Krauss, R. M., Jakobsen, M. U., Bischoff-Ferrari, H. A., ... \& Despres, J. P (2016) Does milk consumption contribute to cardiometabolic health and overall diet quality? Canadian Journal of Cardiology, 32(8), $1026-1032$. [Google Scholar] [GcrossRef]

Lowe, P. A. \& Reynolds C. R. (2006). Examination of the psychometric properties of the Adult Manifest Anxiety Scale-Elderly Version scores. Educational and Psychological Measurement, 66 (1), 93-115. [Google Scholar] [CrossRef]

Moschis, G. P. (2003). Marketing to older adults: an updated overview of present knowledge and practice. Journal of Consumer Marketing, 20(6), 516-525. [Google Scholar] [CrossRef]

Petterson, P. (2007). Demographic correlates of loyalty in a service sector. Journal of Service Marketing, 21 (2), 112-121.

Pettigrew, S., Mizerski, K. \& Donovan, R. (2005). The three «big issues» for older supermarket shoppers. Journal of Consumer Marketing, 22 (6), 306-312. [Google Scholar] [CrossRef]

Rozenber, S., Body, J. J., Bruyere, O., Bergmann, P., Brandi, M. L., Cooper, C., ... \& Rizzoli, R. (2016). Effects of dairy products consumption on health: benefits and beliefs - a commentary from the Belgian Bone Club and the European Society for Clinical and Economic Aspects of Osteoporosis, Osteoarthritis and Musculoskeletal Diseases. Calcified Tissue International, 98(1), 1-17. [Google Scholar] [CrossRef]

Rundh, B. (2009). Packaging design: creating competitive advantage with product packaging. British Food Journal, 111 (9), 9881002. [Google Scholar] [CrossRef]

Rybanska, J., Polat, D., Nagyova, L., Andocsova, A., \& Geci. (2019) A. consumer behaviour and promotional strategies differences on the market of milk in Turkey and Slovakia. Proceedings Book, 108. [Google Scholar] [CrossRef]

Suchanek, P., \& Kralova, M. (2018). The Influence of Costumers' Personal Characteristics on their Satisfaction with the Food Industry. Journal of Competitiveness, 10(4), 151-170. [Google Scholar] [CrossRef]

The Dairy Alliance. (2019). Flavored Milk. Retrieved from http://southeastdairy.org/flavored-milk/

Valaskova, K., Kliestikova, J., \& Krizanova, A. (2018). Consumer perception of private label products: An empirical research. Journal of Competitiveness, 193), 149. [Google Scholar] [CrossRef]

Олександра Кривошикова, Словацький аграрний університет в місті Нітра (Словацька республіка);

Яна Рибанська, Ph.D., Словацький аграрний університет в місті Нітра (Словацька республіка);

Людмила Надьйова, Ph.D., Словацький аграрний університет в місті Нітра (Словацька республіка),

Андрій Геці, Словацький аграрний університет в місті Нітра (Словацька республіка).

Споживча поведінка осіб літнього віку на ринку коров'ячого молока в Словаччині: техніки переконання

У статті проаналізовано основні сегменти споживачів на ринку молока у Словаччині. Авторами зазначено, що особи літнього віку вважаються непривабливим сегментом споживачів через їх обмежену купівельну спроможність. При цьому результати аналізу свідчать про зростання кількості осіб літнього віку у Словацькій республіці, що обумовлюе старіння нації. Вважається, що до 2050 року четверта частина населення Європи буде віком старше 65 років. У зв'язку з цим дослідження споживчої поведінки та процесу прийняття рішень людьми літнього віку є нагальним та актуальним. У статті розглянуто споживчу поведінку людей літнього віку на ринку коров'ячого молока для якого характерний найвищий рівень попиту у Словацькоїреспубліки. Метою статті $\epsilon$ аналіз споживчих переваг осіб літнього віку та їх критерії прийняття рішень при купівлі коров'ячого молока. Авторами зазначено, що дослідження спрямовано на пошук візуальних індикаторів, які привертають увагу споживачів. Детерміновану вибірку даних сформовано на основі результатів опитування 470 респондентів (з яких 210 чоловіків та 260 жінок) віком від 61 до 84 років. Використання психологічних інструментів та короткого анкетування встановлено, що у Словацькій республіці особи літнього віку надають перевагу традиційним мотивам та яскравим кольорам на упаковці молока. На основі отриманих результатів встановлено, що порівняно із молоддю, особи літнього віку більш лояльні до певної продукції та брендів, а також вважають ціновий фактор вирішальним ніж якість молочної продукції приії купівлі. Авторами проаналізовано та систематизовано різні точки зору дієтологів щодо користі коров'ячого молока. Отримані результати засвідчили, що молоко $є$ невід'ємним компонентом щоденного раціону харчування не лише дітей, але і дорослих, особливо, людей літнього віку. При цьому оскільки у осіб літнього віку відсутній необхідний фермент (лактаза) для руйнування молочного цукру (лактози), у рамках даної статті приведені рекомендації щодо споживання молока, яке не містить молочного цукру за рахунок ферментації, упроцесі якої виникає молочна кислота. Кисломолочні продукти (сир, йогурт та кефір) сприятливо впливають на шлунок та імунну систему. У свою чергу, тривала недостатність кальцію в організмі спричиняе остеопороз - захворювання, яке проявляється втратою кістково тканини та деформацією кісток, що призводить до їх переломів та підвищує ризик виникнення інших ускладнень зі здоров'ям. Результати анкетування підтвердили, що для осіб із високим ступенем невротизму, упаковка відіграє значну роль при прийнятті рішення щодо купівлі молочних продуктів. Результати дослідження можуть бути використані менеджерами молочних компаній при формуванні стратегії промоції власної продукції.

Ключові слова: коров'яче молоко, особи пенсійного віку, споживча поведінка, упаковка, методи переконання.

Manuscript received: 22.11.2019.

(C) The author(s) 2020. This article is published with open access at Sumy State University. 